\title{
Sri Lanka's Role in the World Trade Organization
}

\author{
Ajantha Geeganage \\ Thammasat University Bangkok, Thailand \\ ajanthagee@gmail.com
}

\begin{abstract}
As the key regulatory body of the international trading system, it is important to analyze Sri Lanka's position and its role in the WTO system with regard to two aspects. First, to get an understanding about the country's whole trade regime, its development and its direction. Second aspect is, as a founding member of the GATT and later the WTO, it is important to study about its evolution, achievements and its current position. Further, there are trading partners at bilateral, regional and global levels and scholars who are interested in this field who wish to know Sri Lanka's current trading position or its role in the WTO. According to Sri Lanka's trade and economic interests, NAMA, Agriculture, Trade Facilitation, Services, TRIPS, Rules and Aid for Trade are the most important areas as per priority in descending order. Within these areas Sri Lanka's role in the WTO negotiations has been active.
\end{abstract}

Key Words: World Trade Organization, International Trade Liberalization, Protectionism, Small, Vulnerable Economy, Doha Development Agenda

\section{Introduction}

The WTO, or World Trade Organization is an Inter-Governmental Organization (IGO) functioning under Most Favored Nation, (MFN) basis is one of the leading 'rule-based' and 'member driven', International Trade Organizations (ITO). Although its life began on the $1^{\text {st }}$ of January1995, the trading system is not so young it is more than six decades old. Since 1948, the General Agreement of Tariff and Trade (GATT) served the system and GATT was adapted to the WTO when it was reborn in 1995. Basically, the WTO system is running through agreements which are born out of negotiations and cover six main areas of: goods, services, intellectual property, agreement establishing WTO, dispute settlement and trade policy reviews. Being a good forum for multilateral trade negotiations, the WTO covers a wide area of comprehensive activities, but it runs on a few basic fundamental principles. With its legal binding status, the WTO helps its 157 members $^{1}$ to solve their trade matters through the dispute settlement mechanism while liberalizing their trade. Being one of the twenty three founding members ${ }^{2}$ of the GATT, Sri Lanka (Ceylon) has been a contracting party to the GATT since 1948. Sri Lanka also ratified the Marrakesh Agreement in 1994, became a member of the WTO at its beginning, January 1995. With ratification of the WTO agreement, Sri Lanka has agreed to undertake its commitments for almost all WTO's agreements. Since the late 1970s, Sri Lanka has shifted towards a more open economic policy regime with the unilateral liberalization of its trade policies and removing its closed import substituting policies. However, the country has changed its direction of trade from the 1990s and later on with the WTO Doha Round's status, paying increasingly more attention on regional and bilateral levels especially other Asian, Middle-Eastern and emerging economies for integration with global markets. Sri Lanka is a small, vulnerable economy worth US \$ 64 billion with a population of 21,481,334 (July 2012 est.) currently at a transition period after ending its civil war in May 2009. In its history, Sri Lanka passed through three long colonial eras of the Portuguese, the Dutch and the British in 1505, 1660 and 1802 respectively until it became independent from the British Empire in February, 1948. Following the political unrest for an official language, it faced the 1971 uprising and the 26 year conflict with the Liberation Tigers of Tamil Eelam (LTTE). After resolving all these unpleasant situations, Sri Lanka is in a transition period moving towards development. It also has a stable political situation with peace and harmony. The main objective of the study is to analyze Sri Lanka's position or role in the WTO negotiations. This paper is organized in six sections. The first section provides a brief introduction. The second section provides a brief overview of Sri Lanka's history

\footnotetext{
${ }^{1}$ As of August 2012 the WTO has 157 member states and 27 observer governments

2 GATT's founding members: Australia, Belgium, Brazil, Burma, Canada, Ceylon, Chile, China, Cuba, the Czechoslovak Republic, France, India, Lebanon,

Luxembourg, Netherlands, New Zealand, Norway, Pakistan, Southern Rhodesia, Syria, South Africa, the United Kingdom, and the United States
} 
with the GATT. The third section provides a detailed analysis of Sri Lanka's role at the WTO Doha Round including the Doha process, actors and the key areas of the round such as Agriculture, Non-Agricultural Market Access (NAMA), Services, Trade Related Aspects of Intellectual property Rights (TRIPS), Trade Facilitation and Rules areas which are most important for Sri Lanka's interest. The fourth section examines Sri Lanka's role beyond the WTO. The penultimate section presents a brief overview of the theoretical concerns of the study. Finally, the last section of this paper presents a conclusion and future prospects.

Sri Lanka in the GATT History: Within its 47 year history, the GATT has conducted eight rounds of trade negotiations. The initial five rounds only considered further reduction of tariffs. The sixth round, the Kennedy Round, in the mid the 1960s, looked beyond initials and put anti-dumping measures on the negotiating table. In the Tokyo Round, in the mid-seventies it made a first attempt to improve the GATT system through framework agreements. Non-tariff measures were the other area considered beyond the progressive tariff reductions. The final round, the Uruguay Round (UR) was the most successful trade negotiation round the WTO system ever had. The number of subject areas taken into account was fifteen and all agreements were compiled into the WTO Legal Text ${ }^{3}$. The most significant achievement of the round was that it led to the creation of WTO. Sri Lanka has been a founding contracting party to the GATT since 1948 and became a founding member of the WTO in 1995. As a member, Sri Lanka was represented in all GATT rounds. In 1977, with the introduction of open economic policies unilaterally, Sri Lanka became the first South Asian country to initiate liberal trade policies. Those open economic policies assisted the country to maintain average annual economic growth rate at a considerable level, more than five per cent continuously except the 1986-90 period (3.4 per cent), when it had fallen due to the foreign exchange rates and external debt problems which the government had to face. In compliance with the GATT objectives, Sri Lanka has almost fully liberalized external trade and its achievements were supreme in both imports and exports, it had rapid growth over the post-1977 period. Exports were expanded by 5,960.69 percent from Rupees 6,638 million in 1977 to Rupees 402,308.5 million in 2000 while imports were enhanced by 7,848.88 per cent from Rupees 6,007 million in 1977 to Rupees 477,489.2 million in 2000. With the Uruguay Round commitments, Sri Lanka has already fixed its 'bound' tariff on agricultural imports at a uniform rate of 50 per cent. That was the lowest not only among the South Asian countries but also many of the developing countries and some of the developed countries. The scope of tariff bindings on industrial products was small, but it was with the same ceiling rates as in agriculture. The Tariff Commission of the country has recommended a three band tariff system of 35 per cent, 20 per cent and 10 per cent in the year of 1995. Sri Lanka is not considered a country which provides export subsidies. Even though Sri Lanka provides domestic support in several ways, still it is within the de-mimimis level ${ }^{4}$. Although Sri Lanka is not a signatory party to the Agreement on Government Procurement, the Government of Sri Lanka practices an open tender system for government procurement. State trading was limited to imports of petroleum, arms and explosives. The rest is handled by the private sector. In terms of the WTO environmental consideration, Sri Lanka is much ahead, not only in the South Asian region, but also the rest of the world. Moreover, Sri Lanka is among the six top most countries, which are protecting the ozone layer, compliant with the Montreal Protocol. Sri Lanka's significant compliance with the GATT's ruling system has been accepted by the WTO secretariat itself through its trade policy review reports for Sri Lanka. Moreover, Sri Lanka's role in the WTO also had a progressive improvement from an inactive position in the beginning to a moderate level when it came to the Uruguay Round period.

Sri Lanka's Role at the WTO Doha Round: As the main analytical section of the paper, in this section Sri Lanka's current position at the WTO Doha Round will be analyzed. Therefore, Doha process, key actors of the Doha Round and core areas of the Doha Round which are important to Sri Lanka will be analyzed in order to assess Sri Lanka's role.

\section{Doha Process}

The WTO's current round of negotiations, the Doha Round was launched at the Fourth Ministerial Conference in Doha, Qatar, in November 2001. The entire area of subjects that are being negotiated is called the "Doha

${ }^{3}$ WTO, "The Legal Tests: The Results of the Uruguay Round of Multilateral Trade Negotiations" (Cambridge, UK, Cambridge University Press, 1999), pp.1492.

${ }^{4}$ Minimal amounts of domestic support that are allowed even though they distort trade - up to $5 \%$ of the value of production for developed countries, $10 \%$ for developing 
Development Agenda" (DDA). The original deadline announced to conclude the round was the $1^{\text {st }}$ of January, 2005. After missing the deadline, it had an unofficial target of the year 2006. Likewise, several deadlines came and went over the last eleven year period but the round is still inconclusive. The Fifth Ministerial Conference in Cancún, Mexico, in September 2003, was conducted as a stock-taking and organized how to complete the rest of the negotiations of the round. A new actor, the G20 emerged and became prominent. Agricultural and Singapore issues ${ }^{5}$ heated the Cancun conference and collapsed with agricultural issues including cotton, and ended in deadlock on the "Singapore issues" as the official reason. But its unofficial reason was new emerging strong attitudes of G20 opposing the developed actors. Time to time different faces and attempts have been made to continue and move forward the Doha round such as the July 2004 package, the July 2008 package etc. But the Doha Round has yet to be concluded. At the WTO Hong Kong Ministerial conference in 2005, Singapore issues were replaced by NAMA and GATS, which gave more advantages to the developed countries and then the more developed developing countries like China, India, etc. The poorest countries' gains from the round are still at a minimal level.

Actors of the Doha Round: After the WTO's Uruguay Round, no longer are the developed countries of the West able to fix the agenda for the trade negotiations, as the case was under the GATT. For the first time in the history of WTO, most of the agreements which were agreed upon in the Uruguay Round gave priority to the developing nations. It has become a critical juncture of the multilateral trading system as no longer are the developing countries like India, China, Brazil etc., silent partners of the Doha Round. These advanced developing countries as such, now referred to as emerging economies, are becoming strong actors in the game, and are making more demands and being asked to undertake more sustainable liberalization from the West. With the various and numerous interests of the WTO membership of 157 countries including developed and developing economies, it has been possible to accommodate into various homogeneous and heterogeneous alliances and groupings at the Doha Round. In this scenario, the most important actors and groups which are recognized are the US, the EU, G20, G33, the African Groups, LDCs and the ACP group. In addition to that, there are number of $G$ groups formed based on various interests of the WTO members. Asia Pacific Economic Cooperation (APEC), MERCOSUR, Cairns group, Small and Vulnerable Economies (SVEs) ${ }^{6}$ for Agriculture, NAMA and Rules, Recently Accessed Members (RAMs), G10, NAMA 11 are some of them. Moreover, many of the members are represented by more than one group as per their interest. Activities and the interests of the different actors and groups are causing progress or delaying the Doha Round. More details of the actors and the groupings of the Doha round are as follows;

The US: The US is not only a founding member of the GATT and later on the WTO, but also one of the leading creators of the World Trading system. It is also one of the most powerful actors who has set the negotiation agenda until very recently. The US is one of the WTO members who provide export subsidies and domestic support for their agriculture products on large scales to keep their production cost lower and compete with developing countries. Providing export agriculture subsidies is prominent in many products including cotton. Agricultural export subsidies ${ }^{7}$ and domestic supports were one of the key elements for the failure of the Cancun Ministerial conference. The US and the EU were the main culprits for that failure. Agriculture is an important sector of the US economy. Although agricultural production contributed less than 0.8 percent to US GDP in 2009, it contributed 6 percent of total exports and 3 percent of total imports. Further, employment in the sector was around 1.4 percent of the civil labor force. Also, the value of agricultural production of the US was registered at US \$ 195 billion in 2002, US \$ 311 billion in 2007 and US \$ 287 billion in 2009. Moreover, the US is the World's largest producer of several agricultural products, such as soybeans, maize, beef, chicken meat, and milk. It is also the second or third largest producer of barley, wheat, sugar beet, and several fruits and vegetables. Being the largest economy in the World, the US's GDP was US \$ 15.29 trillion (2011 est.) under purchasing power parity and the real figure was US \$ 15.09 trillion (2011 est.) making it the world's second largest GDP after the EU. Its total exports were registered at US \$ 1.497 trillion in 2011 as the world's third largest exporter and total imports were recorded at US \$ 2.236 trillion in 2011 and became the world's largest importer. However, the US is the leading power on introducing capitalism and market liberalism to

5 Four issues introduced to the WTO agenda at the December 1996 Ministerial Conference in Singapore: trade and investment, trade and competition policy, transparency in government procurement, and trade facilitation

${ }^{6}$ Applies to Members with economies that, in the period 1999 to 2004, had an average share of (a) world merchandise trade of no more than 0.16 per cent or less, and (b) world trade in non-agricultural products of no more than 0.1 per cent and (c) world trade in agricultural products of no more than 0.4 per cent ${ }^{7}$ An export subsidy is a benefit conferred on a firm by the government that is contingent on exports 
the world as the hegemon. Changing its attitude towards a more protectionist stance will affect all actors of the Doha Round. Since the large American consumer market is very important for almost every country and region in the world, reducing consumption in the American market would affect most countries' exports and would result in an economic downturn worldwide.

The EU: The EU has also been a full member of the WTO since it was established in 1995. Although the EU countries have single-signed individual membership in the WTO, the EU speaks with one voice at the WTO negotiations. The EU itself is a member of the WTO. Though the members have a certain degree of authority, the European Commission negotiates at the WTO on behalf of the EU. Currently, the EU consists of 27 member countries and faces difficulty in acting as a single voice in WTO negotiations. Even though it has both intergovernmental and supranational status, it would have to agree to each proposal internally before presenting it at the Doha Negotiations. This situation directly caused a delay in the Doha Round itself, although it has raised a single EU-voice at the Doha Round. The EU is a very important actor for the whole membership of the WTO since it has become the most powerful trading bloc in the world with the GDP under purchasing power parity at US \$ 15.65 trillion (2011 est.) and its real value at US \$ 17.33 trillion (2011 est.). The EU's total exports were registered at US \$ 1.791 trillion in 2010, making it the world second largest exporter after China. Its total import was recorded at US \$ 2 trillion in 2010 again becoming second largest importer in the world after the US. Agricultural production contributed to around 1.6 percent of the gross value added (GVA) for the entire economic sector in the EU in 2009 while contributing to 5.1 percent of employment. In 2010, agricultural products contributed to 6.7 percent of EU's total exports and 5.7 percent EU's total imports. The EU is another WTO member that provides export subsidies and domestic support on a large scale. The EU is prominent in providing domestic support ${ }^{8}$ to their agriculture by providing technology, machinery, equipment etc., for their farmers. The US differs from this by providing agricultural export subsidies for their farmers on a large scale rather than domestic supports. As per the Organization for Economic Co-operation and Development (OECD) estimation, in 2009, the EU's total support to the agriculture sector was over $€ 100$ billion, which equals to nearly one third of the total value of production and its support to producers was estimated to be about $€ 87$ billion. The EU's export subsidy regime has not changed substantially over the past few years. Under its WTO commitments, the EU can use export subsidies for 20 different product groups. The amount of export subsidy varies from product to product and market to market. In 2011, export subsidies were provided for cereals, beef and veal, poultry meat, pig meat, eggs, sugar, and some processed goods.

The G20 Group: Since the WTO's Cancun Ministerial conference in 2003, the Group of Developing Countries (G20) is a powerful actor in the WTO negotiations. Although the G20 bloc was established on the $20^{\text {th }}$ August, 2003 officially, its origin was back in June, 2003, when foreign ministers from Brazil, India and South Africa signed the Brasilia Declaration. Currently the G20 consists of 23 member countries from different regions of the world. Brazil, India and South Africa are leaders of the group. Even though China is represented in the G20 group, its role is invisible because China is still considered as a new WTO-member (joined in 2001) and is still living off its accession commitments. The G20 is also an important factor in the WTO. Today the G20 accounts for 60 percent of the world's population, 70 percent of the world's farmers and nearly 26 percent of the world's agricultural exports. Since it consists of Brazil, India and China, being emerging economies, they would be the leaders of the new world order. According to the latest projections, in early 2016, China will overtake the US economy. The G20 raised its voice at the WTO's fifth Ministerial meeting against the developed countries of the world, basically against the US and EU export agricultural subsidies and Singapore issues. To strengthen their argument they tried to emphasize that they raised their voice on behalf of all developing nations. But in reality they represent the advanced developing countries and their requirements. In this regard, developing countries' interest in G20 was weakened to a certain extent by the WTO's next Ministerial meeting, Hong Kong in 2005, since many developing countries recognized G20's real attitude. However, Brazil, India and China being prominent and stable economically and becoming more powerful as the leaders, achieved their objectives of getting what they wanted. Brazil and India were absorbed into other leading negotiation groups such as G4 and G6 as well. With this situation, South American countries, like Brazil are playing a remarkable role independently from North America, the US for the first time. As a result

${ }^{8}$ In agriculture, any domestic subsidy or other measure which acts to maintain producer prices at levels above those prevailing in international trade; direct payments to producers, including deficiency payments, and input and marketing cost reduction measures available only for agricultural production 
the debt crisis of the West did not affect them unlike in the past. This is a substantial achievement of the South American countries, which goes beyond the Doha Round. The leaders of the G20 have been intending to get more benefits through greater trade liberalization of the developed countries, while protecting their own markets. They called it agricultural protectionism. Ultimate results of NAMA ${ }^{9}$ and service liberalization also would be the same, India and China getting more benefit from this under the category of developing countries. They would enjoy the benefits of development under the umbrella of developing countries prior to removing their barriers which obviously would harm the poorest countries in the world.

LDCs and the African Group: Least developed countries (LDCs), the African group and the group of African, Caribbean and Pacific countries (APC) include many of the same members. The United Nations has recognized 48 countries (registered) as the least-developed countries and 33 of them which are currently members of the WTO and form the LDC group are raising one voice in some cases. Many of them are from the African region and currently Bangladesh is leading the LDCs group. To a certain extent their voice is positive in WTO's negotiations. Even though the Doha Round was known as the development round, the LDCs gained the least, according to some scholars' analysis. However, the WTO Doha Round's special and differential treatment (S\&DT) is an achievement for LDCs. It is obvious that other areas of the Doha Round would not be able to fulfill LDCs interests of what they expect from the Doha Round. However, LDCs contribution to world trade has improved, but still depends on only a few and its benefits are also limited to a few. LDCs are in an alliance with the African group and ACP to form the G90 group. The African group consists of 42 members, all African WTO members. Many of them represent the LDC group also. They raised their voice on agricultural market access, especially cotton products and its subsidies, against developed countries, as well as working for increase in aid for the members and S\&DT. Most of these states are members of the African Union as well, which also led to economic development of the members. The region is suffering from many problems such as food crisis, civil wars, corruption, and especially health problems like HIV /AIDS and drug and human trafficking.

The ACP Group and the G33 Group: The group of African, Caribbean and Pacific countries (ACP) has 58 members which include many of the same LDCs and African group and 10 WTO observers. The ACP has raised its voice on four issues at the Doha Round, which are agriculture including subsidies, TRIPS compulsory licensing of medicines and patent protection, review of provisions in regard to the principle of S\&DT and the further addressing of the developing countries' problems when implementing current trade obligations of the Uruguay Round. As mentioned, the ACP is also in an alliance with LDCs and the African group to create the G90 group in order to enhance their demands in the Doha negotiations. At times, the G90 joins alliances with the G20 for issues of interest to them in order to go for a win-win situation at the Doha negotiations without losing the gains. The group of 33 developing countries (G33) was also created at the WTO based on the agricultural issues. Currently, the group consists of 46 members and some them are leaders of the G20 group, such as India and China. Sri Lanka is also represented in this group for her agriculture interests. The group is also recognized as "Friends of Special Products" in agriculture. Alliance of the developing countries is pressing for flexibility from the developed countries to undertake limited market opening for their agriculture products.

\section{The Areas of importance to Sri Lanka}

Although the entire package of DDA consists of 21 different subject areas, in her trade and economic interests, Sri Lanka has paid more attention on a few areas such as agriculture, NAMA, services, TRIPS, trade facilitation, rules and aid for trade.

Agriculture: Agriculture has been one of the key areas of concern since the GATT was established, but not often put on the negotiation table until the WTO was established in 1995 and later on it was included in the DDA. Agriculture is the most important area for developing countries more than for the developed countries, since it contributes vastly to economic development by generating a higher percentage of employment in developing countries. Providing food and better health are other added advantages for them. In the case of developed countries, agriculture contributes a low amount to their GDP while providing the same low

${ }^{9}$ Non-agricultural market access: broadly covers industrial, fisheries and forestry products 
percentage of employment. Since their economies are too vast, value-wise contribution is so high and therefore, it is still important. In terms of free trade and trade liberalization's gains, agriculture would be the first according to many studies. Its estimation accounted for nearly half or 50 percent of the total gain from the full liberalization. Therefore, it is no surprise that agriculture is considered as the heart of the Doha Round. In this situation, agriculture coupled with the higher degree of protectionism through tariffs not only in the developing countries but also in the developed countries, subsidies are widespread more in the developed world and the developing world to a certain extent. Therefore, developing countries are not willing to remove their trade barriers on agriculture to be in line with the developed countries, which is very similar to the removal of export subsidies on agriculture from the developed world. However, according to many studies, agriculture's contribution to the world is on a declining trend. This situation is reflected in most of the developed and developing countries' individual status on agriculture as well. In the 1960s, agriculture's contribution to the world's GDP was about 10 percent, which has declined to 3.33 percent today. But most of the developing countries' economies depend on agriculture heavily. Not only their economic status, it is also linked with a few other matters beyond trade such as food security, food safety, rural jobs and economies, health, environmental concerns, animal welfare so on. Therefore, in this regard, the WTO cannot address agricultural trade matters solely, it must be considered simultaneously with other non-trade concerns. Therefore, agriculture should be handled from a wide angle than the rest of negotiating areas such as NAMA and services etc. to preserve certain flexibilities especially for the developing countries.

According to the Agreement on Agriculture (AOA), agricultural issues are fourfold. Three of them are directly related to elimination of trade barriers, which are market access (tariff), domestic supports and export competition (export subsidies). The other one is sanitary and phytosanitary issues. According to the modalities proposed in the WTO Draft Texts under the DDA, issued in December 2008, developed countries shall reduce their final bound tariffs in six equal installments over a five year period in accordance with the given tiered formula. The developing countries shall reduce their final bound tariffs in eleven equal annual installments over a ten year period under the given tiered formula for them. In addition, the Draft Text includes further flexibilities for small, vulnerable economies and recently accessed members (RAM) on their tariff reductions. LDCs need not reduce their bound tariffs and they can access developed countries market duty-free and quota-free. Moreover, the text consists of comprehensive details of tariff quotas, tariff escalation, tariff simplifications, special agricultural safeguards (SSG), special safeguard mechanism (SSM), commodities, special products, long-standing preferences and preference erosion and much more. Within the Revised Draft Modalities for Agriculture, domestic supports have been described comprehensively. Domestic support is also subjected to elimination under the proposed reduction formulas for the developed and developing countries separately. The developed countries' reduction should be implemented by six steps over five years. The reduction in Final Bound Total Aggregate Measurement of Support applicable to developing country members shall be $2 / 3$ of the given developed countries formula. The developing countries' reduction should be implemented in nine equal annual installments over eight years, commencing on the first day of implementation. Here again, also there are different flexibilities for RAM's and LDCs. Under export competition (export subsidies), the developed countries should eliminate their remaining scheduled export subsidies by the end of 2013. The developing countries have a little flexibility, should eliminate their export subsidies in equal annual installments by the end of 2016. Under the Hong Kong Ministerial Declaration, developing countries have a further continuous elimination period up to 2021, an extra five years after the end-date for elimination of all forms of export subsidies.

Considering the key actors' perspectives, the EU has been prominent in providing domestic supports followed by the US, Japan, South Korea, Brazil, Thailand etc. The US has been at the top of the countries that provide export subsidies, followed by Australia, Canada and some EU countries. However, later, despite the opposition of France, the EU has made considerable effort to liberalize agriculture. But the US has always been on the negative side of the agricultural demands of the developing countries (protectionism) apart from cotton, which is considered a sensitive area of the US. Moreover, the US has always demanded reciprocity as the counter-offer from the developing countries. This situation is not only for agriculture but also for other sectors as well, which caused the US to be blamed by the G20 and the EU, "the US is too ambitious which is away from the development commitments". These unrealistic ideas of the US also caused the delay in the whole round. Furthermore, advanced developing members of the G20, like Brazil, one of the world's largest exporters of agricultural products, demanded the elimination of the developed countries' barriers on 
agricultural products ${ }^{10}$. At the same time they adopted agricultural protectionism, protecting their market without opening for others. This situation is again harmful for low income developing countries rather than for the developed countries. For the African region, many of which are categorized as LDC, agriculture is an important sector with niche opportunities. However, it has been denoted that continuously reducing their world market share in agriculture, they are following advanced developing countries' perspectives through protectionism. In the case of LDCs, they are not intending to make any agricultural liberalization as they have the facility of S\&DT.

Sri Lanka's Position: Agriculture is the second most important sector for the country and remains a corner stone of the country's economy. Its contribution to GDP was 11.9 percent in 2010 which has reduced to 11.2 percent in 2011. Total agricultural exports were registered at US \$2,306.4 million in 2010 with 26.7 percent share to the total exports in 2010 has increased to US \$2,527.8 million in 2011, but its share contribution to the total exports has reduced to 23.9 percent. As described, Sri Lanka has already fixed its bound rate for agricultural imports at 50 percent. Applied tariff ${ }^{11}$ rates are reducing from time to time with its budget proposals. Around 70 percent of the rural population depends on this sector for their livelihoods directly employing 32.6 percent of the labor force and accounts for 23.9 percent of merchandise exports in 2009. Sri Lanka's average applied MFN tariff ${ }^{12}$ for agricultural products has increased from 21.3 percent in 2003 to 25.6 percent in June 2010 with tariffs on agricultural products ranging from zero to 250 percent. Tobacco products, beverages, and spirits bear the highest tariffs for public health reasons, they are followed by fruits and vegetables, and live animals. Sri Lanka provides domestic support for its farmers in several ways, but it does not exceed the de minimis level. Therefore, the country is falling into the Green box category. Sri Lanka is not recognized as a country which provides export subsidies. In terms of Sri Lanka's perspective in agriculture negotiations, the country is continuously in line with the negotiations under WTO's Revised Draft Modalities for Agriculture. Sri Lanka works with like-minded WTO members in order to protect domestic agriculture, especially subsistence agriculture, rural livelihood and farmers rights against an adverse impact on imports through WTO's flexibilities. At the same time, the country considers food security too. The proposed modalities would allow for developing countries to regulate import surges by introducing measures under Special Safeguard Mechanism (SSM). This situation is very important to protect both farmers and consumers. Sri Lanka used to apply these measures to protect inland agriculture. Sri Lanka's status is quite specific; she is a developing country, Small, Vulnerable Economy (SVE). It is also a Net Food Importing Developing Country (NFIDC) ${ }^{13}$. In this respect, with regard to market access, tariff reductions of agricultural products under DDA, Sri Lanka has several more options with flexibilities than other developing countries. As a SVE, first, after selecting a tiered reduction formula which is introduced for the developing countries, Sri Lanka would have to further moderate by 10 percentage points together with the entitlement of keeping a certain percentage of tariff lines under Special Products. The Second, Sri Lanka could consider as many products as her wishes as Special Products and could undertake only an average tariff cut of 24 per cent. There is no need to resort to formula tariff cut or justify its selection of Special Products through defined indicators. Both these options provide plenty of policy options for protecting domestic agriculture, especially subsistence agriculture and rural development besides NFIDC's flexibilities.

Non-Agricultural Market Access (NAMA): Non-agricultural products refer to all products not covered by the Agreement on Agriculture. This includes a large number of products and product ranges. Today, it represents more than 90 percent of the worlds' merchandise trade. NAMA process covers reducing or eliminating tariffs and eliminates non-tariff barriers (NTBs) particularly on exporting goods from developing countries. However, the Doha negotiations in this sector have been progressing slowly. Developed countries have been making a significant effort and commitment on liberalization of the non-agricultural sector, which is the most important sector for them. Until the Uruguay Round, developing countries did not have much interest to reduce or bind their industrial tariffs within the multilateral trading system. With this situation, in the case of tariff reduction under the GATT, the developed countries had to eliminate their industrial tariffs

\footnotetext{
10 Defined for the coverage of the WTO's Agriculture Agreement, by the agreement's Annex 1. This excludes, for example, fish and forestry products. It also includes various degrees of processing for different commodities

11 Duties that are actually charged on imports. These can be below the bound rates

12 Normal non-discriminatory tariff charged on imports (excludes preferential tariffs under free trade agreements and other schemes or tariffs charged inside quotas)

${ }^{13}$ As per the classification of the United Nations Food and Agriculture organization
} 
by higher degrees than the developing countries. Therefore, the developed countries had to make a tremendous effort to include non-agricultural products as the counter-offer in order to access the developing countries' markets. However, later on, support from the developed countries to non-agricultural product liberalization declined to a certain degree with the rise of fast-growing economies or newly industrialized economies like China. The competition and challenge also increased since China became prominent in the industrial world by specializing in low-cost production of non-agricultural products. It became an added comparative advantage for China. Developed countries such as the US have begun to realize that, it is more important to change the exchange rate of China than liberalization in non-agricultural products. In the WTO system, Chinese excess productivity on non-agricultural products caused certain problems, including a large number of anti-dumping cases from many trading partners against China. In addition, Chinese low-cost based excess production of non-agricultural products directly affected not only the developed countries' economies but also it caused t many problems in the developing countries' economies as well including LDCs.

At present, not only the developed countries but also the developing countries' economic share contributions from non-agricultural products are rapidly increasing. The developing countries need not to keep their nonagricultural tariff high all the time, but need protection for their industries in order to achieve industrialization. Therefore, developing countries also realize the importance of NAMA. Although many of the developed countries tariffs on non-agricultural products are low, many non-tariff barriers are in place to prevent entry of products from developing countries to their markets. If NAMA is included in the final Doha Agreement, it may be controversial as to who will gain from the system, either developed countries or developing countries including LDCs, or both. According to the WTO's draft text issued in May 2008, which consists of modalities for NAMA also like agriculture, based on the proposed Swiss formula with two coefficients, one for developed countries and another one for developing countries. The implementation period is five years for the developed countries with six equal rate reductions and the developing countries have a longer implementation period, ten years with eleven equal rate reductions. Also, the modalities include certain flexibilities for the developing countries regarding their coefficient chosen to be applied and flexibilities for the developing countries with low binding coverage, small, vulnerable economies, LDCs, and RAMs. Moreover, it has additional flexibilities as supplementary modalities, capacity building measures for LDCs, non-reciprocal preferences for the developing countries and environmental goods. However, according to WTO's information during 2011, the Negotiating Group on Market Access for Non-Agricultural Products made significant progress on parts of the agenda to reduce or eliminate non-tariff barriers (NTBs) to trade. But it has made little or no progress in tariff negotiations.

Sri Lanka's Position: In the area of NAMA, with her status, Sri Lanka's position is unique. Sri Lanka is a small, vulnerable economy and Net Food Importing Developing country (NFIDC). With its commitments to WTO Uruguay Round agreement, Sri Lanka has only bound 26 percent of non-agricultural tariffs. Sri Lanka has already fixed its bound level for non-agricultural products at a low level like in the case of agricultural products. Applied tariff levels are also at a low level. In this situation, if the country increases its binding coverage, the country would obviously be at a huge disadvantage than any of the other countries. Therefore, Sri Lanka has raised this issue at the Doha negotiations, asking for exemptions. The WTO membership realized the negative impact to the country and approved the exemptions. This was included in the NAMA text, in paragraph six of the original text (In paragraph 6 of the first version of the NAMA text and later it becomes paragraph 8). This paragraph is called the "Sri Lankan paragraph" unofficially. Later, few other countries having similar disadvantages, allied together and formed the group, 'Paragraph 6' countries in the NAMA negotiations. NAMA is the most important sector for the country with its trade and economic interests. The sector contributed 28.7 percent of the national GDP in 2010, increased to 29.3 percent, with a growth of 10.3 percent in 2011 . Its value accounted for US $\$ 6,726.05$ million in 2010 , increased to US $\$ 7,587$ million in 2011. The total value of industrial goods exported by the country which stood at US $\$ 6,096.1$ million with 70.7 percent share to the total exports in 2010 has boosted to US $\$ 7,991.7$ million achieving 75.7 percent share of the total exports in 2011. That was 31.1 percent growth compared to the year 2010. Sri Lanka's average MFN tariff for non-agricultural products was registered at 9.2 percent in 2010 which is an 8 percent increase compared to the year-2003. This is a considerably low level of average MFN tariffs of the country compared to other developed and developing countries in the world. Tariffs of non-agricultural products range from zero to 30 percent. The categories which obtained highest average MFN duties based on protection include leather, rubber, footwear, and travel goods, with average rates of 18.6 percent followed by 
transport equipment (15.4\%), wood, pulp, paper, and furniture (14.4\%), mineral products (13.3\%), and electrical machinery $(10.3 \%)$. Imported raw materials for export industries are duty free. Sri Lanka has bound only about $26 \%$ of the tariff lines of non-agricultural products with an average bound rate of 21.3 per cent. In 2009, some products exceeded the bound tariff ${ }^{14}$ levels also. According to WTO's trade policy review 2010 of Sri Lanka, NTBs were relatively low. But a range of non-agricultural products such as chemicals, some textiles, and motor vehicles are subject to non-automatic import licenses ${ }^{15}$. The number of tariff lines which required import licenses in 2010 was 520.

In terms of Sri Lanka's perspectives in NAMA negotiations, with its low binding coverage, Sri Lanka is subjected to less tariff reduction commitments in the NAMA negotiations. As already explained, Sri Lanka has already bound less than $30 \%$ of its tariff lines at the Uruguay Round negotiations and applied tariffs are also at a low level, therefore, Sri Lanka had been recognized as a country which would have to undertake disproportionate commitments if the general tariff reduction formula is applied. As a result, Sri Lanka is exempted from making tariff reductions through the formula; instead she only needs to commit to bind $80 \%$ of its non-agricultural tariff lines at an average of 30\%. This has an opportunity to keep $20 \%$ tariff lines unbound. It also has a flexibility to determine Sri Lanka's bound commitment on the basis of sensitivity over the remaining $80 \%$, while maintaining an average of 30\%. In terms of market access for Sri Lanka's export products, Sri Lanka would enjoy benefits overall from tariff reduction commitments agreed to by its export markets. Since the formula for the tariff cuts functions under the basis of higher the tariff, higher the cut, it will be subject to reduced higher and peak tariff to levels well below 5-10\%. However, in case of apparel export to the US and EU, the country has been affected by the proposed tariff reduction implementation periods of the US and EU, which is subjected to a ten year delay for certain products including apparel. In this regard, due to deep cuts in general tariffs in these markets, preference-receiving countries would be affected by preference erosions, thereby losing their comparative advantage. On the other hand, the US and EU would be able to identify products for delay in tariff reduction. In this situation, Sri Lanka together with Pakistan, Bangladesh, Nepal and Cambodia, have been recognized as "disproportionately affected countries" (DAC) which have to be given a separate solution. The DACs will receive tariff reductions over a five-year period rather than ten years separating them from other countries. In this regard, Sri Lanka and Pakistan would be receiving this concession from the US and EU only for five products out of a number of products selected by the country for delayed tariff reductions and five products from the US list for Bangladesh, Cambodia and Nepal. Sri Lanka continuously engages in negotiations with the hope of enjoying more benefits.

Services: In the WTO system, the GATS functions as the framework agreement, but the Members are yet to decide on the limitations of its market access. Its basic objectives and principles are: "progressive liberalization as enshrined in relevant GATS provisions, appropriate flexibility for developing countries, with special priority to be given to least-developed countries and reference to the needs of small and mediumsized service suppliers, particularly of developing countries commitment to respect "the existing structure and principles of the GATS. In the Doha Round, the GATS were put on the negotiating table as the developed countries' counter-offer at the expenses of agriculture. Being the top service provider to the world, the EU made a strong effort to include services into Doha negotiations. That was also beneficial for India, as an advanced developing country who is the large producer and exporter of services, to catch up on the game. Services would then give a comparative advantage not only to the EU but also to India. Although most of the developing countries' internal trade in the services sector is becoming more popular with rapid growth, their external trade in the services sector is probably in a weak position. If so, what would be the gain from developing countries' perspective? This is the reason for GATS negotiations achieving slow progress. Since the GATT was the counter-offer for agriculture, the progress of the GATS negotiation would depend on the progress of agriculture, and, NAMA. Even though the WTO issued modalities for agriculture and NAMA in December 2008, the GATS did not come up with such modalities or progress. However, according to WTO, GATS negotiations are progressing since 2011. In December 2011, the WTO Ministerial Conference approved a waiver allowing WTO members to deviate from its basic principle, most-favored nation obligation of nondiscrimination, in order to provide preferential treatment to services and service suppliers from LDCs.

14 Tariff binding: Commitment not to increase a rate of duty beyond an agreed level. Once a rate of duty is bound, it may not be raised without compensating the affected parties

15 The need to obtain a permit for importing a product; administrative procedures for obtaining an import license 
Sri Lanka's Position: Although Sri Lanka does not have much external trade in services and it generates a low income compared to non-agricultural and agricultural sectors, its domestic trade in the services sector is giving the highest contribution to the country's economy (GDP). Therefore, trade in services is also an important sector for the country. The services sector has contributed to Sri Lanka's GDP by $59.3 \%$ with its value at US \$13,882.88 million in 2010 which increased by $8.6 \%$, contributing to the GDP $59.5 \%$ valued at US $\$ 15,416.26$ million in 2011. The total external trade in services has generated a net income of US \$1,099 million in 2011, registering a remarkable growth of $55.45 \%$ compared to the year of 2010. In 2010, its net income was US \$ 707 million. Further, its sub-sectors wise income generation was transportation US \$1,392 million (30.8\% growth), travel and tourism US \$ 1,196 million (44.2\% growth), information services US \$ 355 million (34\% growth) and communication services US \$ 85 million (2.4\% growth) during 2011. Under Uruguay Round commitments, Sri Lanka had committed only three services sectors. Those are tourism (such as hotel and lodging, and travel agency and tour operators' services), telecommunication and financial services. Sri Lanka also accepted the Reference Paper on Regulatory Principles for Basic Telecommunication Services as an additional GATS commitment. Moreover, under commitments to services sector liberalization, Sri Lanka inscribed horizontal limitations and conditions pertaining to some forms of commercial presence. Under Doha Round negotiations, Sri Lanka has already submitted her initial offers for improving the commitments of existing committed sectors such as tourism, telecommunication, and financial services. Sri Lanka's trade in services sector can be described as follows: Sri Lanka maintains a defensive move for the trade and services liberalization under GATS, careful analysis and conscious policy decisions are needed to explore the potential liberalizations under GATS and the efforts of liberalization of Sri Lankan services sector are driven by monopolistic industry behavior and the overall welfare gain to the economy has been greatly ignored.

Trade Related Aspects of Intellectual Property Rights (TRIPS): In the WTO system, it is believed that ideas and knowledge are an increasingly important part of trade. For the first time in the WTO, TRIPS was negotiated in the Uruguay Round from 1986-1994. Afterwards it became an agreement and one of the three basic pillars. It is not limited to the trade in goods but also includes the trade in services too. Moreover, the WTO's basic responsibility for TRIPS is protecting the intellectual property rights of its member trading partners. The DDA, initially included TRIPS on the basis that it protects the Geographical Indications (GIs) particularly for wines and spirits. The process consists of notification and registration of GIs. The TRIPS Council will put forward the scope and modalities in this regard to the next WTO's Ministerial Conference in 2013. With respect to consultations on outstanding implementation issues, consultations are continuously taking place regarding extension of GI in other areas and GI's relationship between TRIPS and Convention on Biological Diversity (CBD). In April this year, the chairperson circulated a draft text which is the first time a single text reflecting members' proposals and positions taken at the negotiations was circulated, but the text was far from an agreement. All WTO members intend to protect their own intellectual property rights by being members of the "Agreement on Trade Related Aspects on Intellectual Property Rights", with the hope that the agreement may cover the scope of all members' interests. Some scholars argue that intellectual property rights have become a monopoly of a few powerful members.

Sri Lanka's Position: Sri Lanka considers TRIPS as important subject for protecting the country's intellectual property rights. Like in previous issues, at negotiations under the TRIPS also, Sri Lanka got together with likeminded Members on two main areas. The first one is geographical indications (GIs), where Sri Lanka participated in discussions in order to protect and respect all Members GIs. GI defines specific geographical origin which possesses qualities, reputation or characteristics of goods which are essentially acquired and characterized by the place of origin, such as Ceylon Tea, Ceylon Cinnamon and Sri Lankan sapphire. Today, all GIs have to be protected in order to avoid consumers' are misled and to escape from unfair trade practices or competition. The second area where Sri Lanka has an interest is the Convention on Biological Diversity (CBD). As a biodiversity-hot-spot, Sri Lanka necessarily needs protection for its natural resources. Therefore, Sri Lanka again engaged in negotiations under the TRIPS Agreement with like-minded Member countries based on issues of bio-piracy related to the country's rich biodiversity. Sri Lanka introduced new comprehensive intellectual property legislation in 2003, which was intended to ensure compliance with the TRIPS Agreement. The new Act undertakes protection of copyright and related rights, industrial designs, patents, marks and trade names, layout designs of integrated circuits, unfair competition and undisclosed information, and geographical indications. By the new Act, the term of copyright protection has been extended from life 
plus 50 years, to life plus 70 years. Although the country has reinforced the enforcement of IPRs, still counterfeiting and piracy ${ }^{16}$ areas have some problems.

Trade Facilitation: Trade Facilitation (TF) is the only remaining area of the Singapore issues (SIs), where developed countries, especially the EU was concerned as the core area and included in the Doha Round from the beginning of the Round. Although the Cancun Ministerial collapsed with SIs, considering its benefits and requirement for the developing countries, developing countries also agreed to accommodate trade facilitation in the DDA. The new Trade Facilitation Agreement was formally launched in July 2004 (July 2004 Package) as part of the DDA, which is subject to negotiation. Under this mandate, Members are directed to clarify and improve GATT Article V (Freedom of Transit), Article VIII (Fees and Formalities connected with Importation and Exportation), and Article X (Publication and Administration of Trade Regulations). TF negotiations, which are handled by negotiating groups, are aimed at expediting movements, release and clearance of good including transit goods by building up cooperation among customs and other related authorities. In the process, priority will be given to developing countries and LDCs, which stand to benefit by far-reaching flexibilities and extensive technical assistance and capacity-building support. According to WTO information, TF negotiations are moving fast from 2011 by minimizing its gray areas. The negotiations are carried out in bottom-up, member-driven, inclusive and transparent manner. The draft text was issued in 2009 and it has been revised 11 times by the end of 2011 .

Sri Lanka's Position: With the country's trade and economic interest, Sri Lanka identified TF as an important area for the country. Sri Lanka has actively participated in the text-based negotiations on the proposed Agreement on Trade Facilitation (ATF). A draft text has been produced after a series of negotiations on diverse proposals concerning three basic areas of harmonization and regulation in trade facilitation during the five year period: freedom of transit, fees and formalities connected with importation and exportation, and publication and administration of trade regulations. Parallel to text-based negotiations, the other important area of negotiation is provision of Special and Differential Treatment (S\&DT), to meet the special needs of developing countries in implementing the proposed ATF. These S\&DT negotiations take in to account issues such as scheduling of timelines of commitments and categorization of commitments based on whether a country can implement immediately or would require technical assistance to do so.

Rules: Negotiations in Rules is also an important area for all WTO Members since it makes provision to implement or correct existing rules in order to achieve basic objectives. At the Doha Ministerial Conference, the WTO membership has agreed to negotiate rules on the basis of clarity and improvement of rules in three different areas. Those areas are: anti-dumping, subsidies and countervailing measures, and regional trade agreements (RTAs). In the area of subsidies, particular focus is on discipline on fisheries subsidies. At the Hong Kong Ministerial conference in 2005, the Membership agreed broadly on strengthening the discipline with some prohibitions of certain forms of fisheries subsidies which affect overcapacity and over fishing. Negotiations on all agreed areas have taken place. In April 2011, the Chair for the anti-dumping and subsidies and countervailing measures Negotiating Groups on Rules issued a new text on anti-dumping, but it consisted of some same gray areas like in the previous texts. On subsidies, only a report was issued since there was no advantage in a new text. In the area of fisheries subsidies, after a series of Negotiating Groups meetings, the Chair has only come up with a detailed analytical report. In respect to RTAs, the negotiations resulted in 2006 with the General Council's decision on a transparency mechanism for RTAs, which has been applied provisionally since 2007, but it was subjected to be reviewed, and outcome was announced in 2011 by the Chair. Yet to be received are the Membership comments on the legal relationship between the mechanism and WTO provisions on RTAs.

Sri Lanka's Position: On Sri Lanka's perspectives in the area of rules negotiations, it was recognized as an important area for the country. Therefore, Sri Lanka has been participating in the negotiations on three basic areas of the Agreements on Anti-dumping, Subsidies and Countervailing Measures, particularly fisheries subsidies, and on Regional Trade Agreements. In the area of anti-dumping, procedures of imposition of antidumping duties is prominent among the range of issues which have been undertaken. Areas such as subsidies

\footnotetext{
${ }^{16}$ Unauthorized copying of materials protected by intellectual property rights (such as copyright, trademarks, patents, geographical indications, etc) for commercial purposes and unauthorized commercial dealing in copied materials
} 
and countervailing measures (SCM), which have been unfair for small countries like Sri Lanka, are important for the country. For example, the negotiation under Annex VII (b) of SCM agreement is important to continue the concessions granted for foreign investors in Export Processing Zones. Sri Lanka cosponsored this proposal submitted to the Negotiation Group of Rules. There are several other rules negotiation issues important for Sri Lanka from the point of view of export offensive interest to tighten or restrict use of trade remedial measures for protection of domestic industries. Since tariffs are lowered, there is fear that countries will resort to measures such as anti-dumping, countervailing and safeguard provisions. Fisheries subsidies and correction of rules on RTAs are also important for the country. However, when considering Sri Lanka's overall role in the WTO negotiations, it shows a significant improvement with active participation, particularly in the areas where Sri Lanka has interests under its trade and economic interests.

Sri Lanka's Role beyond the WTO: There are many trade and economic connections which Sri Lanka is pursuing beyond the WTO. Indo-Sri Lanka Free Trade Agreement (ISFTA) and Pakistan-Sri Lanka Free Trade Agreement (PSFTA) are bilateral collaborations currently maintained by the country. In addition, two Comprehensive Economic Partnership Agreements (CEPA) agreements are being negotiated with India and Pakistan. Asia Pacific Trade Agreement (APTA), South Asian Preferential Trading Agreement (SAPTA), South Asian Free Trade Area (SAFTA), SAARC Agreement on Trade in Services (SATIS), Bay of Bengal Initiative for Multi-Sectoral Technical and Economic Cooperation (BIMST-EC) and Indian Ocean Rim Association for Regional Cooperation (IOR-ARC) are existing regional preferential trading agreements. In addition, Sri Lanka is currently collaborating in ten bilateral Joint Commissions on Trade, Economic \& Technical Cooperation with Bangladesh, China, Egypt, India, Iran, Iraq, Kuwait, Maldives, Pakistan and Thailand. Furthermore, Sri Lanka engages with another multilateral inter-governmental organization, the United Nations' Conference on Trade and Development (UNCTAD) and is a participant in its Global System of Trade Preference (GSTP) scheme. Sri Lanka is receiving preferences from more than forty countries under the Generalized System of Preference (GSP) schemes of EU, USA, Australia, Canada, Japan, Switzerland, Norway, New Zealand, Poland, Belarus, Bulgaria, Czech Republic, Slovakia, Hungary and Russian Federation. Therefore, Sri Lanka's role beyond the WTO is very active and the country's trade policy direction is more and more towards bilateral and regional relations, as is the global trend. Although Sri Lanka has been complying with the WTO system since its beginning, but, gains from the system is minimal. Therefore, Sri Lanka has more interests in other areas beyond the WTO.

\section{Theoretical Explanation of the Findings}

As the theoretical explanations of this paper, theories of international relations: neo-realism, neo-liberalism or neo-liberal institutionalism and the hegemonic stability theory and theories of international trade: neoclassical liberal economic theory and neo-Recardian comparative advantage theory will be used to explain Sri Lanka's (and other actors') attitude, behavior and position in the selected areas of the WTO Doha Round. In the WTO negotiations it is quite obvious that, every country is trying to maximize their gains through accessing others markets as their state interest while protecting their own market as their state behavior. Additionally, areas selected by Sri Lanka are important to the country as per her interests and has been participating actively in preserving its state interest. This is the idea of neo-realism. As explained, Sri Lanka is basically in line with the WTO system, its agreements, rules and trade liberalization than her regional neighbors and many developing countries and sometimes even more than the developed countries. Furthermore, Sri Lanka has collaborations with different kinds of actors in order to maximize its gain. It has been liberalizing all sectors as per the protocol. This is the phenomenon of neo-liberalism. According to the neo-classical liberal economic theory of international trade, international trade being based on pure free market forces, eliminating subsidies and tariffs as government protectionist instruments in a liberalized multinational trading system (MTS), is the long-term goal of the WTO. The system follows this theory focusing on free trade through eliminating tariffs and subsidies while reducing protectionism. The functions of the system are eliminating tariffs and trade distortions.

It is quite natural that elimination of tariffs and other barriers give more provisions not only for Sri Lanka but also for every country to access others markets and directly enhance trade. That is the main reason for Sri

Lanka and all other members to be within the WTO system. This is also the reason for Sri Lanka and all other countries in the world to move towards more and more bilateral and other regional free trade agreements. 
This is reflected clearly in Sri Lanka's history. When the country adopted closed import substitution policies in pre-1977 period, its trade was very low. After introducing export oriented open economic policies in 1977, post-1977 continuously showed a significant boost of external trade in both imports and exports of the country. As per the overview of Neo-Recardian Comparative Advantage Theory of International Trade, different countries or groups of countries specialize in different products, where developing countries specialize in agricultural products and developed countries specialize in non-agricultural products and services as their comparative advantages. Sri Lanka also has comparative advantage in certain products. All areas where Sri Lanka has been actively participating in the DDA also have comparative advantages than many other countries and the country is fighting for that. It is a quite clear phenomenon that, in the WTO system, developed countries of the west such as the US and later on the EU also dominated the negotiation process until very recently (up to the Uruguay Round). They hold the hegemonic power within the system. But no longer are the developed countries of the west leading players of the system or hegemonies in the WTO system. That power has been transferring to emerging economies such as Brazil, India, China, etc. This hegemonic power change and its influence may change the developing countries' role and the position in the WTO too. Initially Sri Lanka's trade policy directions were more towards the Western countries like the US. But today, it has been changing directions more towards the bilateral and regional trade and economic collaborations.

\section{Conclusion}

The specific objective of this study is to assess Sri Lanka's role in the WTO. At the beginning, its role was inactive. When it came to the Uruguay Round or post Uruguay Round period, it was at a moderate level. Finally, at the Doha Round, Sri Lanka's role was more active, especially in the areas in which the country has interest. The WTO is a re-born systematic instrument to handle multilateral trade with 47 years of GATT experience. It has unique decision making bodies and decision making procedures which function under a few fundamental principles. It has its own legal mechanism called the dispute settlement mechanism to settle trading disputes. Sri Lanka is a small, vulnerable economy and a net food importing developing country, which passed three colonial eras, independence and post-independence eras, 1971 uprising era and after finishing the 26 year conflict, is now in a transition period going towards development. It also has a stable political situation with peace and harmony, which is necessary for development. In the history of GATT, Sri Lanka is a founding contracting party of the GATT and thereafter founding member of the WTO. In the GATT history, Sri Lanka has introduced a series of economic and trade policies. Its pre-1977 period was a generally closed and controlled economy, which centered on import-substituting policies. Economic growth was very low. Post-1977 period adopted an open economic system with liberal trade and exchange rate polices. A considerable economic growth was achieved during this period with external trade (imports \& exports) sectors' showing continuous significant boost. However, until the Uruguay Round, Sri Lanka's role in the WTO negotiations was poor or inactive. With Uruguay Round's commitments, Sri Lanka has bound its whole agricultural sector at a lower ceiling rate, 50\%. This rate is not only lowest among South Asian countries and other developing countries but also some developed countries as well. Non-agricultural sector was also bound at the same lower ceiling rate but its binding coverage is low, below 30\% (26\%).

In the Services sector, three sectors of tourism, telecommunications and financial services were committed. When it came to the Uruguay Round, Sri Lanka's role showed an improvement at a moderate level. Basically, Sri Lanka is in accordance with the WTO rules and regulations except in imposing some additional duties and technical barriers like import licenses for certain products. Sri Lanka is not recognized as a country providing export subsidies and even the provision of domestic supports in many ways is still under de minimis level. In terms of the WTO environmental consideration, Sri Lanka is much ahead rest of the world. Even though it got several faces such as DDA, July 2004 Package, and July 2008 Package etc., WTO's current negotiating round is yet inconclusive and no more is its agenda fix by the developed countries of the West i.e. the US and EU like in the past. Positions of its powerful actors such as the US and EU are invaded by new rising actors such as G20 (especially Brazil, India and China). Prominent actors of the round are: the US, the EU, G20, G33, the African Groups, LDCs and the ACP-group. According to Sri Lanka's trade and economic interests, NAMA, Agriculture, Trade Facilitation, Services, TRIPS, Rules and Aid for Trade are most important areas as per priority in descending order. Within these areas, Sri Lanka's role in the WTO negotiations is active. Sri Lanka is undertaking many trade and economic relations beyond the WTO and its trade policies are also towards the 
bilateral and regional directions. However, the WTO is also an essential forum for the country. Therefore, Sri Lanka's future role in the WTO will be active, but its trade policy direction will be more and more towards non-WTO trade and economic collaboration.

\section{References}

Central Bank of Sri Lanka. (2009). Annual Report 2009, Colombo, Sri Lanka, Central Bank Publication), 1-26. Central Bank of Sri Lanka. (2010). Annual Report 2010 (Colombo, Sri Lanka: Central Bank Publication, 1-27 WTO. (2011). Annual Report 2011. Geneva, Switzerland: WTO Publication, 1-186.

WTO. (2012). Annual Report 2012. Geneva, Switzerland: WTO Publication, 84-105.

WTO. (2008). Fourth Revision of Draft Modalities for Non-Agricultural Market Access, TN/MA/W/103/Rev.3, Geneva, Switzerland: WTO Publication, 1-126

WTO. (2008). Revised Draft Modalities for Agriculture. TN/AG/W/4/Rev.4, Geneva, Switzerland: WTO Publication, 1-123

WTO. (2004). The Legal Tests: The Results of the Uruguay Round of Multilateral Trade Negotiations, UK: Cambridge University Press, 1-492.

WTO. (1995). Trade Policy Review of Sri Lanka 1995. Geneva, Switzerland: WTO Publication, 1-24

WTO. (2004). Trade Policy Review of Sri Lanka 2004. Geneva, Switzerland: WTO Publication, 1-137

WTO. (2010). Trade Policy Review of Sri Lanka 2010. Geneva, Switzerland: WTO Publication, 1-128

WTO. (2010). Trade Policy Review of the US 2010. Geneva, Switzerland: WTO Publication, 80-124

WTO. (2003). Understanding the WTO (3ed ed), Geneva, Switzerland: WTO Publication, 1-92. 